\title{
Influence of finely ground limestone on cement hydration
}

\section{J EAN PERA(1)*, SOPHIE HUSSON(1,2), BERNARD GUILHOT ${ }^{(2)}$}

(1) Institut National des Sciences Appliquées de Lyon, Unité de Recherche Génie CivilMatériaux, 20, Boulevard Albert Einstein, Villeurbanne Cedex, France

(2) Ecole Nationale Supérieure des Mines de Saint Etienne ; Centre SPIN ; Département PMMC ; LPMG -UMR CNRS 5148 ; 158 Cours Fauriel, 42023 Saint-Étienne Cedex 2, France

\begin{abstract}
Some work has been carried out on the effect of calcium carbonate on cement paste, but there is no general agreement on the relative effects of different amounts of calcium carbonate on cement paste properties. The objective of the present work is to assess the effect of various amounts of calcium carbonate on the hydration of tricalcium silicate in order to explain the physico-chemical changes occurring during Portland cement hydration. It is shown that calcium carbonate has an accelerating effect on $\mathrm{C}_{3} \mathrm{~S}$ and cement hydration and leads to the precipitation of some calcium carbosilicate hydrate.
\end{abstract}

Keywords:

Calcium carbonate; Calorimetry; Carbosilicate; Cement; Hydration; Infrared spectroscopy; Microstructure; Strength

\section{Introduction}

For a long time, ground limestone has been considered as an inert filler. However, recent studies carried out in the 1980s have pointed out the following phenomena:

* calcium carboaluminate hydrates precipitate during the hydration of cements containing ground limestone [1-7],

* during the formation of ettringite, sulfate ions can be replaced by carbonate ions without modifying the sequences of the reaction [8-11],

* there is an interaction between calcium silicate (alite) and calcium carbonate; the latter accelerates the hydration of C3S and modifies the $\mathrm{Ca} / \mathrm{Si}$ ratio of C-S-H [12$14]$.

As the interactions of ground limestone and $\mathrm{C}_{3} \mathrm{~A}$ are well documented, we have, in the present paper, focused our attention on the reactions which occur during the hydration of $\mathrm{C}_{3} \mathrm{~S}$ in the presence of calcium carbonate. The behaviour of blended Portland cements containing up to $50 \%$ ground limestone has also been investigated.

\footnotetext{
${ }^{*}$ Corresponding author: jean.pera@insa-lyon.fr
} 


\section{Experimental}

\section{II.1. Materials}

\section{II.1.1. Calcium carbonate $\left(\mathrm{CaCO}_{3}\right)$}

The calcite studied was derived from marble and was very pure $\left(98.6 \% \mathrm{CaCO}_{3}\right)$. Its specific gravity was 2.75 .

It was ground to get the following characteristics:

$$
\begin{aligned}
& \text { * } \quad \text { average diameter } \mathrm{D}_{\mathrm{s}} \mathrm{O}=2.5 \mu \mathrm{m} \text {, } \\
& \text { * } \quad 35 \% \text { particle below below } 1 \mu \mathrm{m} \text {. }
\end{aligned}
$$

For this product, the Blaine specific surface area was $680 \mathrm{~m}^{2} \mathrm{~kg}^{-1}$ and the BET specific surface area was $3600 \mathrm{~m}^{2} \mathrm{~kg}^{-1}$

Calcium silicate $\left(\mathrm{C}_{3} \mathrm{~S}\right)$

Calcium silicate was synthesized by reacting a well mixed stoichiometric blend mixture of pure calcium carbonate and reactive silica. The blend was wetted and pellets prepared. The temperature program was as follows:

$$
\begin{aligned}
& \text { * 20-700 }{ }^{\circ} \mathrm{C}: 20^{\circ} \mathrm{C} \mathrm{min}^{-1} \\
& \text { * } 700-1000^{\circ} \mathrm{C} \text { : } 15^{\circ} \mathrm{C} \mathrm{min}^{-1}
\end{aligned}
$$

$\Delta$ temperature maintained at $1000^{\circ} \mathrm{C}$ for $40 \mathrm{~min}$.

$$
\begin{aligned}
& \text { * } 1000-1450^{\circ} \mathrm{C}: 8^{\circ} \mathrm{C} \mathrm{min}^{-1} \\
& \text { * } \quad 1450-1600^{\circ} \mathrm{C}: 5^{\circ} \mathrm{C} \mathrm{min}^{-1}
\end{aligned}
$$

$\Delta$ temperature maintained at $1600^{\circ} \mathrm{C}$ for $120 \mathrm{~min}$.

The residual lime ( $\mathrm{CaO}$ ) was measured by hydrochloric acid titration of a solution containing $250 \mathrm{mg} \mathrm{C}_{3} \mathrm{~S}$ and $100 \mathrm{~mL}$ ethyleneglycol, shaken at $70^{\circ} \mathrm{C}$ for $30 \mathrm{~min}$. The calcination was considered good as the free $\mathrm{CaO}$ content was less than $2 \%$. A well-crystallized triclinic $\mathrm{C}_{3} \mathrm{~S}$ was then obtained and ground in a laboratory ball-mill. Its particle size distribution was characterized by:

$$
\begin{aligned}
& * \quad 100 \% \text { particles below } 80 \mu \mathrm{m} \\
& \text { * } \mathrm{D}_{50}=15 \mu \mathrm{m} \\
& \text { * } \quad 30 \% \text { particles below } 10 \mu \mathrm{m}
\end{aligned}
$$

\section{II.1.2. Ordinary Portland Cement (OPC)}

The cement used in the present study was a CPA CEM I 52.5 according to the European prestandard ENV 197-1 for common cements. Its Bogue potential composition was $\mathrm{C}_{3} \mathrm{~S}=$ $67.9 \% ; \mathrm{C}_{2} \mathrm{~S}=4.8 \% ; \mathrm{C}_{3} \mathrm{~A}=10.4 \% ; \mathrm{C}_{4} \mathrm{AF}=9.3 \%$. Its Blaine and $\mathrm{BET}$ specific surface areas were $364 \mathrm{~m}^{2} \mathrm{~kg}^{-1}$ and $1400 \mathrm{~m}^{2} \mathrm{~kg}^{-1}$, respectively. The average value of the particle size distribution was $\mathrm{D}_{50}=16 \mu \mathrm{m}$.

\section{II.2. Methods used for investigation}

Isothermal calorimetry was used to study the interactions between $\mathrm{C}_{3} \mathrm{~S}$ (or $\mathrm{OPC}$ ) and $\mathrm{CaCO}_{3}$. $\mathrm{C}_{3} \mathrm{~S}$ (or OPC) was mixed with $\mathrm{CaCO}_{3}$ in the weight ratio 1:1. The mixture (300 mg) was then hydrated in presence of the same quantity of water $(300 \mathrm{mg})$. The total heat developed during the reaction was recorded. The length of the experiment was $15 \mathrm{~h}$.

The morphology of these hardened pastes was investigated by means of scanning electron microscopy (SEM), and the hydrates formed were identified, using infrared spectrometry (IRS), X-ray diffraction (XRD) and differential thermal analysis (DTA).

Pastes of pure $\mathrm{C}_{3} \mathrm{~S}$ ( or $\mathrm{OPC}$ ) and $\mathrm{CaCO}_{3}$ were prepared at equivalent consistency. The water to solid ratios are shown in Table 1. 
From Table 1, it is clear that the presence of $\mathrm{CaCO}_{3}$ has a plasticizing effect on the paste: the higher the $\mathrm{CaCO}_{3}$ content, the lower the amount of mixing water. Minicylinders of paste were cast ( $\phi=20 \mathrm{~mm}, \mathrm{~h}=40 \mathrm{~mm}$ ), demoulded after 2 days of hydration, and kept at $20^{\circ} \mathrm{C}$ and relative humidity 95\% until mechanical testing, which occurred after 7, 28 and 60 days of age.

\section{Results and discussion}

\section{III.1. Reactions between $\mathrm{C}_{3} \mathrm{~S}$ and $\mathrm{CaCO}_{3}$}

\section{III.1.1. Isothermal calorimetry}

The isothermal calorimetry curves showing the rate of heat development of $300 \mathrm{mg} \mathrm{C}_{3} \mathrm{~S}$ and (150 mg $\mathrm{C}_{3} \mathrm{~S}+150 \mathrm{mg} \mathrm{CaCO}$ ) during hydration, up to $15 \mathrm{~h}$, are given in Figure 1 . The values recorded for the blend $\left(\mathrm{C}_{3} \mathrm{~S}+\mathrm{CaCO}_{3}\right)$ were always higher than those of hydrated $\mathrm{C}_{3} \mathrm{~S}$.

The total heat resulting from pure $\mathrm{C}_{3} \mathrm{~S}$ hydration was 145 joules, whilst that of the mixture $\left(50 \% \mathrm{C}_{3} \mathrm{~S}+50 \% \mathrm{CaCO}_{3}\right)$ reached 260 joules. These results are in good agreement with those obtained by Ramachandran [14]. They indicate that $\mathrm{CaCO}_{3}$ cannot be considered as an inert addition towards $\mathrm{C}_{3} \mathrm{~S}$ hydration.

\section{III.1.2. SEM examination}

As shown in Figure 2, the pastes presented about the same texture after 7 days of hydration; namely platlets of calcium hydroxide and fibrils of C-S-H. After 60 days of hydration, the morphology of the pastes is different, as presented in Figure 3. In pure $\mathrm{C}_{3} \mathrm{~S}$, platlets of calcium hydroxide and $\mathrm{C}-\mathrm{S}-\mathrm{H}$ type II are present according to Taylor [15]. In ' $\mathrm{C}_{3} \mathrm{~S}+\mathrm{CaCO}_{3}$ ' paste, granules of C-S-H are formed.

\section{III.1.2. Infrared spectrometry}

The IR spectra of hydrated $\mathrm{C}_{3} \mathrm{~S}$ at different ages are shown in Figure 4 . Those of the ' $\mathrm{C}_{3} \mathrm{~S}+\mathrm{CaCO}_{3}$ ' paste are shown in Figure 5. The wavenumbers present in each product hydrated either for one day or 28 days are reported in Table 2 . The vibrations associated with each wavenumber are also presented in Table 2.

In hydrated $\mathrm{C}_{3} \mathrm{~S}$, all the $\mathrm{Si}-\mathrm{O}-\mathrm{Si}$ stretching bands were reorganized between 1 and 28 days. The structure of tobermorite gel was reached [16], as shown by the emboldened wavenumbers.

In the blend ' $\mathrm{C}_{3} \mathrm{~S}+\mathrm{CaCO}_{3}$,' the characteristic bands of the $\mathrm{CO}_{3}$ ion appeared. Some $\mathrm{SiO}_{4}$ bands were shifted after one day of hydration, demonstrating the accelerating effect of $\mathrm{CaCO}_{3}$ on $\mathrm{C}_{3} \mathrm{~S}$ hydration. Those results were also obtained using the diffuse reflectance method, as shown in Figure 6.

The results of XRD investigations are given in Figure 7, after 60 days of hydration. The following conclusions can be drawn from these analyses:

* calcium hydroxide is present in all compositions;

* the intensity of the $\mathrm{C}_{3} \mathrm{~S}$ peak decreases when the amount of $\mathrm{CaCO}_{3}$ increases such that in the blend containing $50 \% \mathrm{CaCO}_{3}$, these peaks have almost disappeared;

* the intensity of the peak at $2 \theta=14.9^{\circ}$ increases with the $\mathrm{CaCO}_{3}$ content and is due to the formation of some hydrated carbosilicate.

The consumption of $\mathrm{CaCO}_{3}$ was studied by means of DTA. The area of the decomposition peak of $\mathrm{CaCO}_{3}$ decreased with the hydration time and the temperature corresponding to the maximum of this peak shifted towards smaller values as shown in Figure 8. Such results were previously observed by Henning [6] in the case of precipitation of carbonate hydrates.

\section{III.1.4. Compressive strength of pastes}

The compressive strength of the different pastes is presented in Figure 9. The presence of $\mathrm{CaCO}_{3}$ at levels higher than $30 \%$ has a beneficial effect on the strength, whatever the hydration time may be.

It is possible to compute the K(t) value for each paste using Feret's formula:

$\mathrm{R}(\mathrm{t})=\mathrm{K}(\mathrm{t})\left(\mathrm{V}_{\mathrm{s} /} \mathrm{V}_{\mathrm{t}}\right)^{2}$ 
where $\mathrm{R}(\mathrm{t})$ is the strength after $\mathrm{t}$ days of hydration, $\mathrm{K}(\mathrm{t})$ is the coefficient of reactivity of the binder, Vs, is the volume of binder, and Vt, the sum of the following three volumes: binder, water and entrained air. In the present study, the volume of air was measured at $1.5-1.6 \%$. Table 3 shows the $K(7)$ and $K(60)$ values obtained for the different pastes. After 7 days hydration, all blended pastes develop higher $\mathrm{K}(7)$ values than pure $\mathrm{C}_{3} \mathrm{~S}$ which proves that $\mathrm{CaCO}_{3}$ reacts chemically. After 60 days hydration, only pastes containing more than $30 \%$ $\mathrm{CaCO}_{3}$, develop higher $\mathrm{K}(60)$ values.

\section{III.2. Reactions between $\mathrm{OPC}$ and $\mathrm{CaCO}_{3}$}

\section{III.2.1. Isothermal calorimetry}

Figure 10 shows that the same type of curve is observed with $\mathrm{OPC}$ and pure $\mathrm{C}_{3} \mathrm{~S}$. The heat produced by the reaction between $50 \%$ OPC and $50 \% \mathrm{CaCO}_{3}$ is about double that issued from plain OPC hydration.

\section{III.2.2. Hydrates formed}

As shown by XRD (Figure 11) carboaluminate and carbosilicate have been precipitated after 60 days of hydration.

The presence of calcium carboaluminate hydrate was also observed by infrared spectrometry (bands at 3670 and $3530 \mathrm{~cm}^{-1}$ ). IR spectroscopy also pointed out differences in $\mathrm{AF}_{\mathrm{m}}$ and $\mathrm{AF}_{\mathrm{t}}$ phases (Figure 12). In the paste containing pure OPC, both monosulphate (bands at 100 and $1170 \mathrm{~cm}^{-1}$ ) and ettringite (band at $1120 \mathrm{~cm}^{-1}$ ) are present. In the paste containing $50 \% \mathrm{CaCO}_{3}$, monosulphate almost disappeared and the band at $1120 \mathrm{~cm}^{-1}$ was reinforced, so some $\mathrm{SO}_{4}$ ions in ettringite were probably replaced by $\mathrm{CO}_{3}$ ions. The band assigned to the $v_{3} \mathrm{SiO}_{4}$, vibration at $970 \mathrm{~cm}^{-1}$ was also slightly modified and that of carbonate at $875 \mathrm{~cm}^{-1}$ amplified.

\section{III.2.3. Compressive strength of pastes}

The compressive strength of pastes is presented in Figure 13. The strength is maintained or even increased in pastes containing $10 \% \mathrm{CaCO}_{3}$. Lower strengths are obtained with higher $\mathrm{CaCO}_{3}$ levels. These results mean that the development of strength is not similar in $\mathrm{C}_{3} \mathrm{~S}$ and OPC pastes containing $\mathrm{CaCO}_{3}$. In OPC, interactions occur between $\mathrm{C}_{3} \mathrm{~A}$ and $\mathrm{CaCO}_{3}$, leading to the production of calcium carboaluminate hydrate and the modification of ettringite, whereas in blended $\mathrm{C}_{3} \mathrm{~S}$ pastes, only calcium carbosilicate hydrate is obtained.

Nevertheless, the level of strength remains acceptable for a $50 \%$ level of OPC substitution: it is $81 \%$ that of OPC alone. This result proves that chemical reactions occur, but in a smaller extent than in $\mathrm{C}_{3} \mathrm{~S}$ pastes and more $\mathrm{CaCO}_{3}$, remains as an inert filler.

\section{Conclusion}

As shown by isothermal calorimetry, more total heat is developed in $\mathrm{C}_{3} \mathrm{~S}$ or cement containing up to $50 \%$ calcium carbonate than in the absence of $\mathrm{CaCO}_{3}$ under comparable conditions signifying the accelerating effect of $\mathrm{CaCO}_{3}$. Hydration of $\mathrm{C}_{3} \mathrm{~S}$ in the presence of $\mathrm{CaCO}_{3}$, results in the production of some calcium carbosilicate hydrate and good mechanical performance for amounts of $\mathrm{CaCO}_{3}$ higher than $30 \%$.

In cement paste, calcium carbonate modifies the $\mathrm{AF}_{\mathrm{m}}$ and $\mathrm{AF}_{\mathrm{t}}$ phases, and produces calcium carbosilicate and carboaluminate hydrates but does not lead to the same strength development as in $\mathrm{C}_{3} \mathrm{~S}$ paste.

\section{References}

[1] A Bachiorrini, Interactions physico-chimiques entre l'aluminate monocalcique et différents carbonates au cours de l'hydratation. Thesis I, Université Claude Bernard, Lyon (1985), p. 215.

[2] A Bachiorrini, AA Fournier, B Guilhot, M Murat, A Negro and M Soustelle, Influence de la calcite sur l'hydratation de l'aluminate monocalcique - Corrélation entre les résultats expérimentaux et la thermodynamique du système. Proceedings of the $8^{\text {th }}$ International Congress on the Chemistry of Cements, Rio de Janeiro, 22-27 September 1986 IV, FINEP, Rio de Janeiro (1986), pp. 376- 380. 
[3] VS Ramachandran, Thermal analysis of cement components hydrated in the presence of calcium carbonate. Thermochimica Acta 127 (1988), pp. 385- 394.

[4] SM Bushnell-Watson and JM Sharp, The detection of the carboaluminate phase in hydrated high alumina cements by differential thermal analysis. Thermochimica Acta 93 (1985), pp. 613-616.

[5] A Bachiorrini and L Cussino, Hydratation du ciment alumineux en présence d'agrégats calcaires. In: Proceedings of the $8^{\text {th }}$ International Congress on the Chemistry of Cements, Rio de J aneiro, , FINEP, Rio de J aneiro IV (22- 27 September 1986), pp. 383388.

[6] O Henning and A Kudjakov, Einfluss von Calcit auf die Hydratation von PortlandZement. Wissenchaftliche Zeitschrift de Hochschule für Architektur and Bauwesen Weimar 29 (1983), pp. 75- 77.

[7] O Henning and A Zkudjakov, Einfluss von Dolomit auf die Hydratation von PortlandZement. Wissenchaftliche Zeitschrift de Hochschule für Architektur and Bauwesen Weimar 27 (1980), pp. 187- 191.

[8] C Vernet, Séquences cinétiques des réactions d'hydratation de l'aluminate tricalcique en présence de gypse, de chaux et de fillers calcaires. Proceedings of the $8^{\text {th }}$ International Congress on the Chemistry of Cements, Rio de Janeiro, 22-27 September 1986 III, FINEP, Rio de Janeiro (1986), pp. 70- 74.

[9] A Negro, G Abbiati and L Cussino, Sur l'emploi du filler calcaire comme régulateur de prise. Proceedings of the $8^{\text {th }}$ International Congress on the Chemistry of Cements, Rio de J aneiro, 22- 27 September 1986 III, FINEP, Rio de Janeiro (1986), pp. 109- 119.

[10] J Bensted, Further hydration investigation involving Portland cement and the substitution of limestone for gypsum. World Cement 14 (1983), pp. 383- 392.

[11] A Bonnin and B Cariou, Système aluminate de calcium gypse-chaux et eau. 7e Congrès International de la Chimie des Ciments, Paris III (1980), pp. 158- 163.

[12] VS Ramachandran and Chun-Mei Zhang, Influenza del $\mathrm{CaCO}_{3}$ sulla idratazione e sulle caracteristiche microstrutturali del silicato tricalcio. II Cemento 3 (J uly/September 1986), pp. 129- 152.

[13] VS Ramachandran and Zhang Chun-Mei, Dependence of the fineness of carbonate on the hydration behaviour of tricalcium silicate. Durability of Buildings Materials 4 (1986), pp. 45- 66.

[14] VS Ramachandran, Cement with calcium carbonate addition. Proceedings of the 8th $^{\text {th }}$ International Congress on the Chemistry of Cements, Rio de Janeiro, 22- 27 September 1986 III, FINEP, Rio de J aneiro (1986), pp. 109- 119.

[15] HFW Taylor, The hydration of tricalcium silicate. Matériaux et Constructions 17102 (1984), pp. 457-468.

[16]. VC Farmer, The Infrared Spectra of Minerals, Mineralogical Society, London (1974). 


\section{Figures}

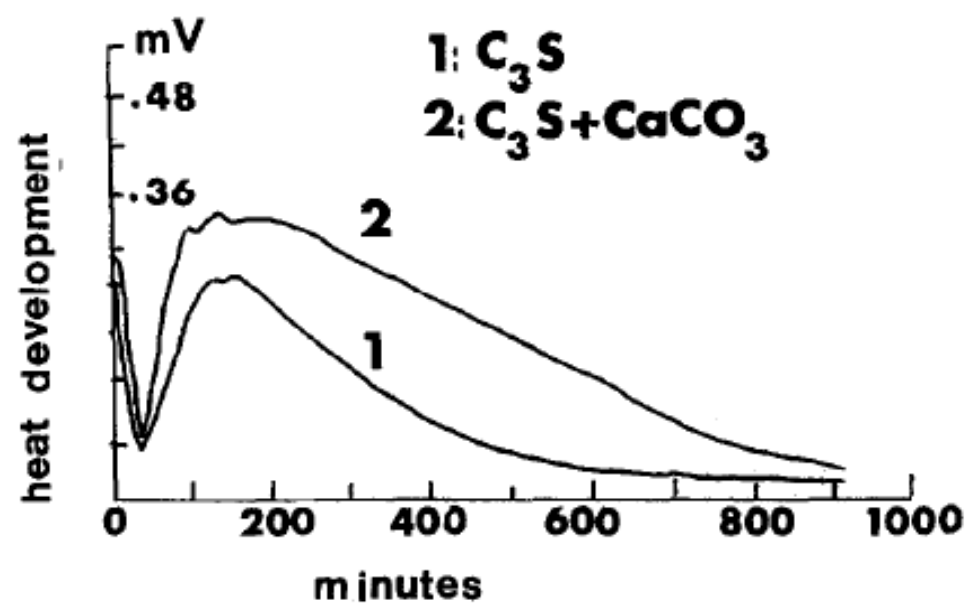

Fig. 1. Isothermal calorimetry data: $\mathrm{C}_{3} \mathrm{~S}$ and $\mathrm{C}_{3} \mathrm{~S}+\mathrm{CaCO}_{3}$.

Figure 1: Isothermal calorimetry data: $\mathrm{C}_{3} \mathrm{~S}$ and $\mathrm{C}_{3} \mathrm{~S}+\mathrm{CaCO}_{3}$.

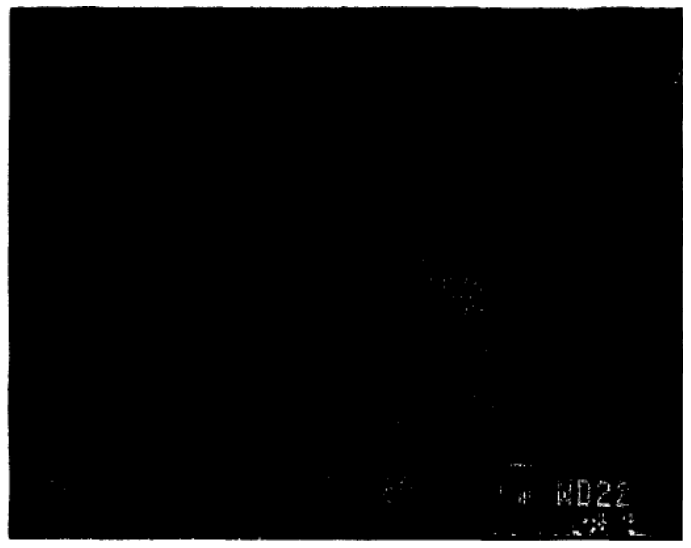

(a)

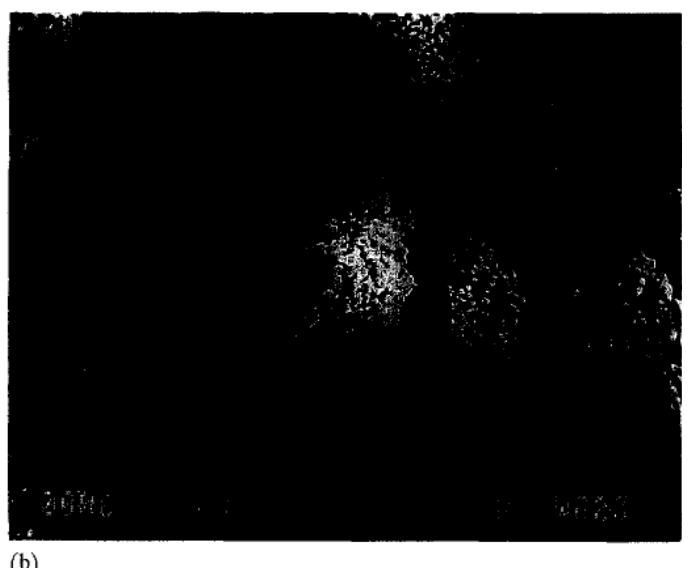

(b)

Figure 2: SEM micrographs after 7 days of hydration. 
Cement and Concrete Composites, 1999, 21(2), 99-105, doi:10.1016/ S0958-9465(98)00020-1

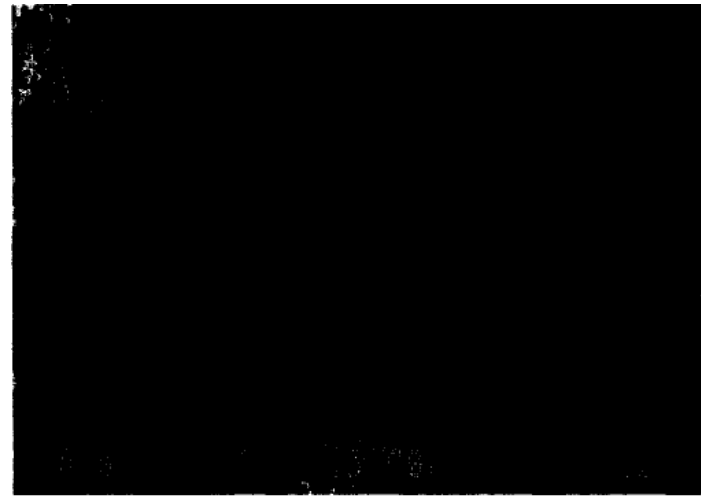

(a)

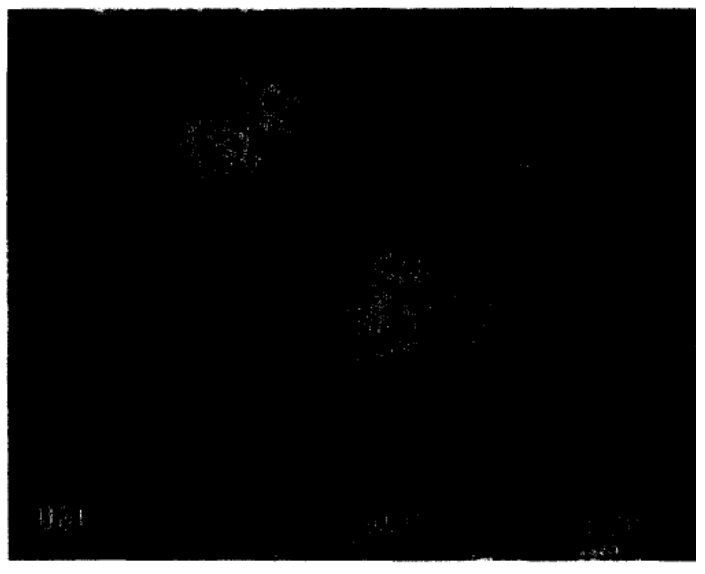

(b)

Figure 3: SEM micrographs after 60 days of hydration.

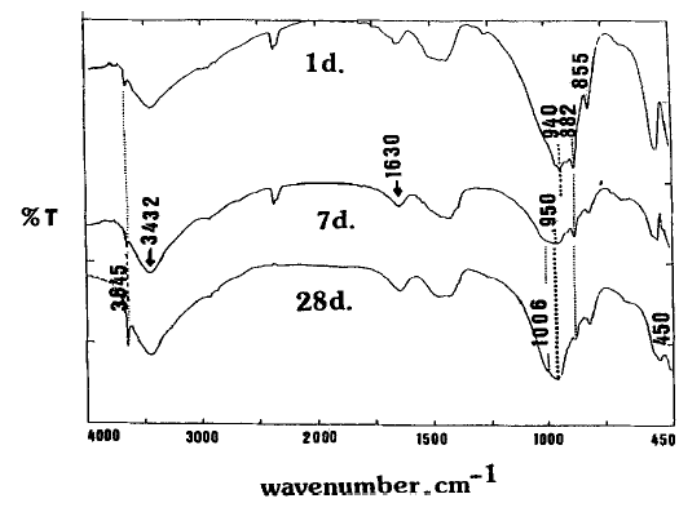

Figure 4: Infrared spectra of hydrated $\mathrm{C}_{3} \mathrm{~S}$.

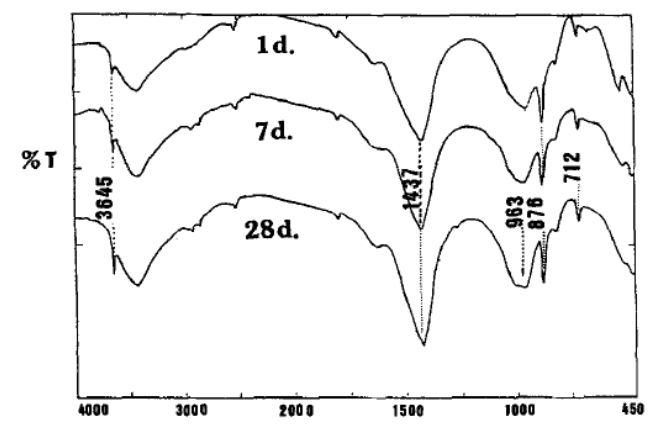

Figure 5: Infrared spectra of hydrated $\left(\mathrm{C}_{3} \mathrm{~S}+\mathrm{CaCO}_{3}\right)$. 

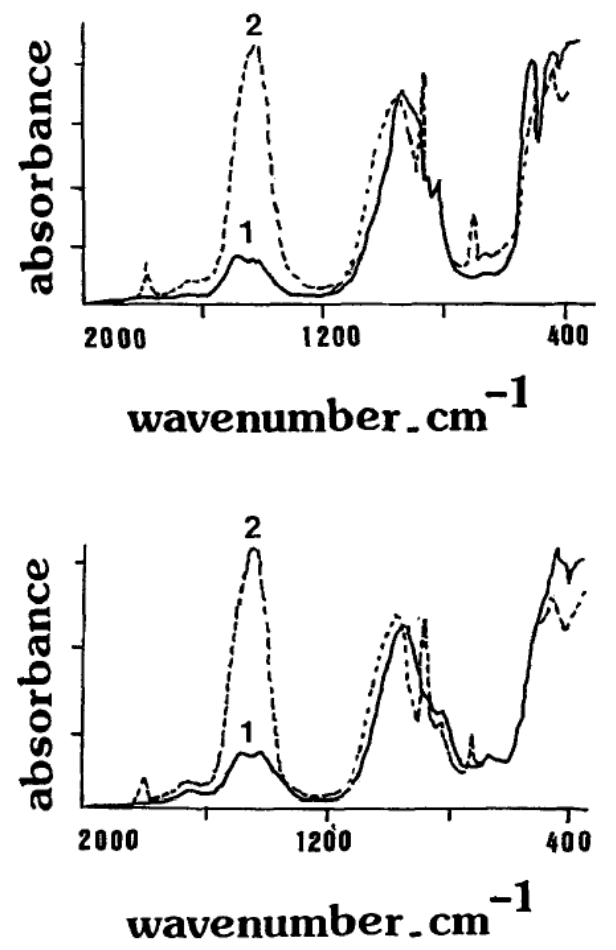

Figure 6: IR spectra obtained from the diffuse-reflectance method.

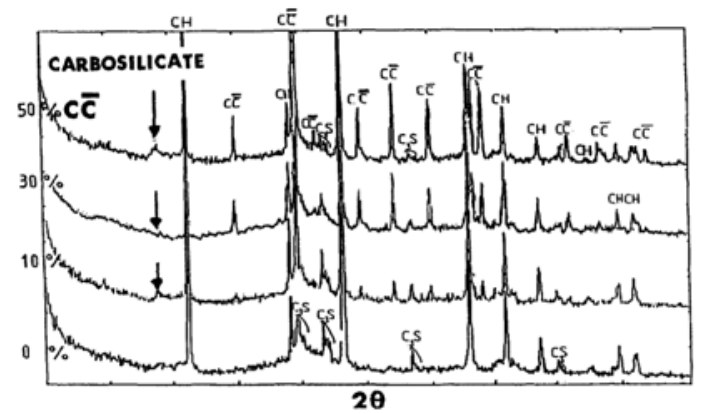

Figure 7: XRD patterns of the different pastes after 60 days of hydration.

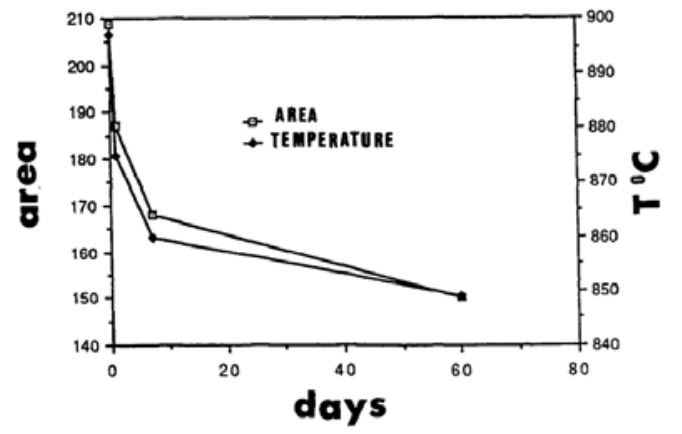

Figure 8: Evolution of the area and the temperature of $\mathrm{CaCO}_{3}$ decarbonation. 
Cement and Concrete Composites, 1999, 21(2), 99-105, doi:10.1016/ S0958-9465(98)00020-1

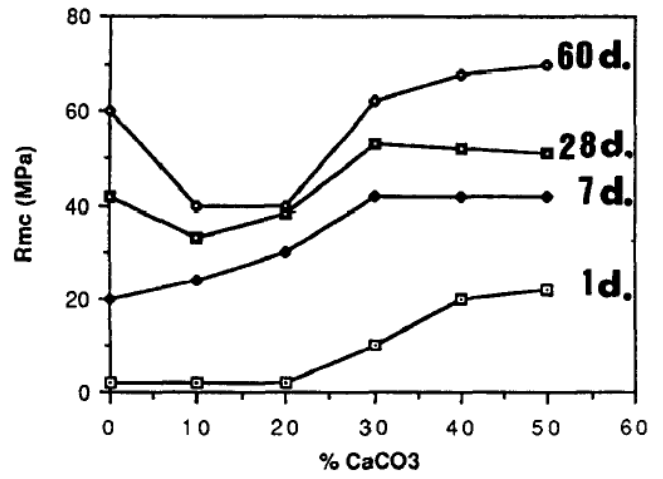

Figure 9: Influence of $\mathrm{CaCO}_{3}$ on the compressive strength of pastes.

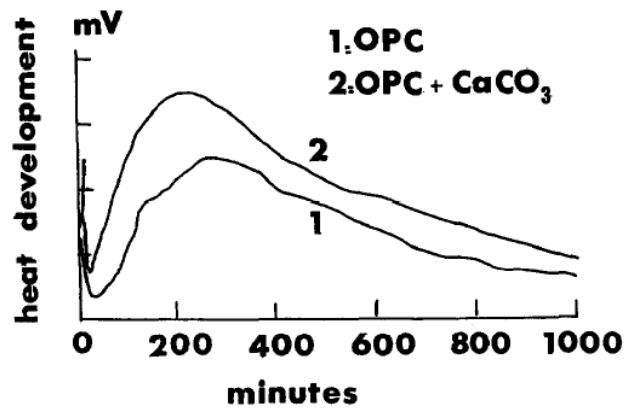

Figure 10: Isothermal calorimetry curves: $\mathrm{OPC}$ and $\mathrm{OPC}+\mathrm{CaCO}$.

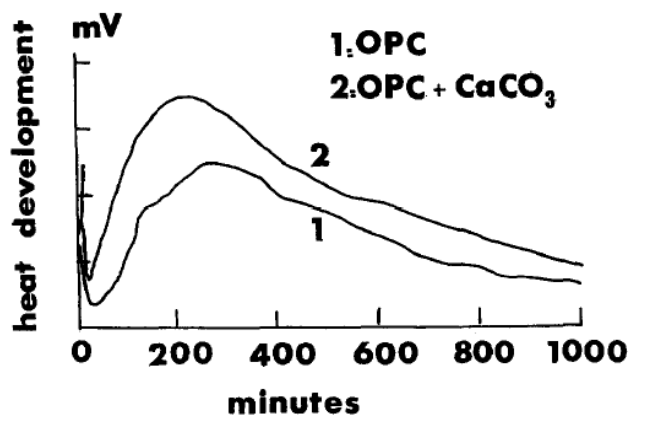

Figure 11: $\mathrm{XRD}$ spectrum of hydrated paste $\left(\mathrm{OPC} / \mathrm{CaCO}_{3}=1\right)$.

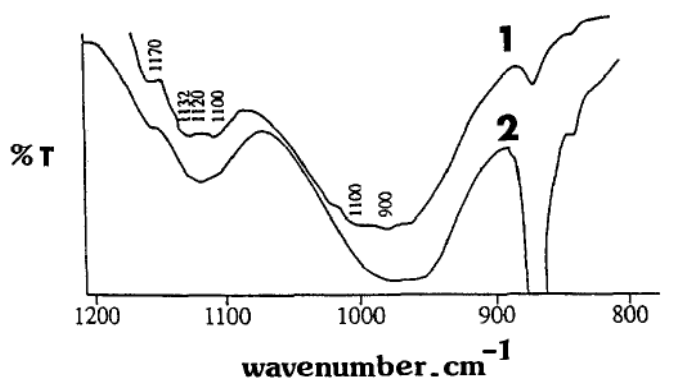

Figure 12: Modification of $\mathrm{AF}_{\mathrm{m}}$ and Aft phases in the paste containing $50 \% \mathrm{OPC}$ and $50 \% \mathrm{CaCO}_{3}$ after 60 days of hydration. 
Cement and Concrete Composites, 1999, 21(2), 99-105, doi:10.1016/ S0958-9465(98)00020-1

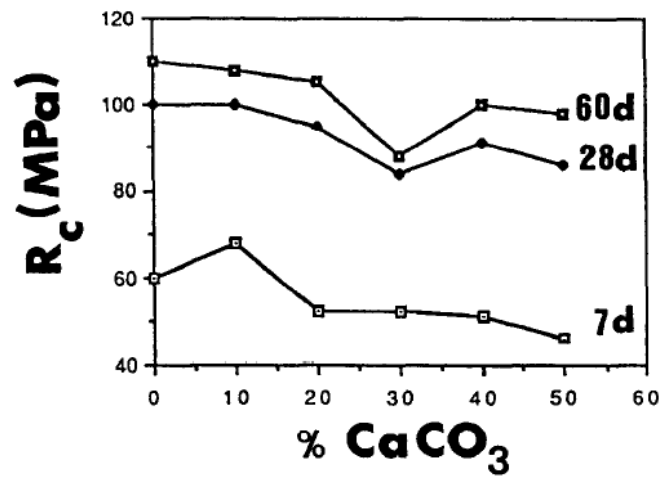

Figure 13: Compressive strength of cement pastes containing different amounts of $\mathrm{CaCO}_{3}$.

\section{Tables}

Table 1: Water to solid ratios of pastes

\begin{tabular}{|l|l|l|l|l|l|l|}
\hline $\mathrm{C}_{3} \mathrm{~S}\left(\mathrm{w}_{\mathrm{t}} \%\right)$ & 100 & 90 & 80 & 70 & 60 & 50 \\
\hline $\mathrm{CaCO}_{3}\left(\mathrm{w}_{\mathrm{t}} \%\right)$ & 0 & 10 & 20 & 30 & 40 & 50 \\
\hline $\mathrm{W} / \mathrm{S} \mathrm{S}=\mathrm{C}_{3} \mathrm{~S}+\mathrm{CaCO}_{3}$ & 0.35 & 0.34 & 0.33 & 0.32 & 0.31 & 0.3 \\
\hline $\mathrm{OPC}\left(\mathrm{w}_{\mathrm{t}} \%\right)$ & 100 & 90 & 80 & 70 & 60 & 50 \\
\hline $\mathrm{CaCO}_{3}\left(\mathrm{w}_{\mathrm{t}} \%\right)$ & 0 & 10 & 20 & 30 & 40 & 50 \\
\hline $\mathrm{W} / \mathrm{S} \mathrm{S}=\mathrm{OPC}+\mathrm{CaCO}_{3}$ & 0.28 & 0.28 & 0.27 & 0.26 & 0.25 & 0.24 \\
\hline
\end{tabular}

Table 2: Infrared results of hydrated $\mathrm{C}_{3} \mathrm{~S}$ and $\left(\mathrm{C}_{3} \mathrm{~S}+\mathrm{CaCO}_{3}\right)$

\begin{tabular}{|c|c|c|c|c|c|}
\hline \multicolumn{3}{|c|}{$\mathrm{C}_{3} \mathrm{~S}$} & \multicolumn{3}{|c|}{$\mathrm{C}_{3} \mathrm{~S}+\mathrm{CaCO}_{3}$} \\
\hline \multicolumn{2}{|c|}{ Wavenumber $\left(\mathrm{cm}^{-1}\right)$} & \multirow[t]{2}{*}{ Vibration } & \multicolumn{2}{|c|}{ Wavenumber $\left(\mathrm{cm}^{-1}\right)$} & \multirow[t]{2}{*}{ Vibration } \\
\hline 1 day & 28 days & & 1 day & 28 days & \\
\hline 1635 & 1630 & $v_{2} \mathrm{H}_{2} \mathrm{O}$ & 1635 & 1635 & $v_{2} \mathrm{H}_{2} \mathrm{O}$ \\
\hline 1480 & 1450 & $v_{3} \mathrm{CO}_{3}$ & 1437 & 1437 & $v_{3} \mathrm{CO}_{3}$ \\
\hline 938 & 960 & $v_{3} \mathrm{SiO}_{4}$ & 1161 & 1161 & $v_{1} \mathrm{CO}_{3}$ \\
\hline 905 & & $v_{3} \mathrm{SiO}_{4}$ & 954 & 963 & $v_{3} \mathrm{SiO}_{4}$ \\
\hline 882 & 882 & $v_{3} \mathrm{SiO}_{4}$ & 876 & 876 & $v_{2} \mathrm{CO}_{3}$ \\
\hline 855 & 855 & v3 $\mathrm{SiO}_{4}$ & 849 & & $v_{3} \mathrm{SiO}_{4}$ \\
\hline \multirow[t]{2}{*}{660} & 665 & $v_{4} \mathrm{SiO}_{4}$ & 712 & 712 & $v_{4} \mathrm{CO}_{3}$ \\
\hline & 640 & $v_{4} \mathrm{SiO}_{4}$ & 660 & 660 & $v_{4} \mathrm{SiO}_{4}$ \\
\hline 518 & & $v_{4} \mathrm{SiO}_{4}$ & 506 & 486 & $v_{4} \mathrm{SiO}_{4}$ \\
\hline 450 & 450 & $v_{2} \mathrm{SiO}_{4}$ & 452 & 462 & $v_{2} \mathrm{SiO}_{4}$ \\
\hline
\end{tabular}


Cement and Concrete Composites, 1999, 21(2), 99-105, doi:10.1016/S0958-9465(98)00020-1 Table 3: Reactivity of the different binders

\begin{tabular}{|l|l|l|l|l|l|l|}
\hline $\mathrm{C} 3 \mathrm{~S}$ & 100 & 90 & 80 & 70 & 60 & 50 \\
\hline $\mathrm{CaCO}_{3}\left(\mathrm{w}_{\mathrm{t}} \%\right)$ & 0 & 10 & 20 & 30 & 40 & 50 \\
\hline $\mathrm{K}(7)$ & 100 & 107 & 129 & 179 & 164 & 157 \\
\hline $\mathrm{K}(60)$ & 225 & 125 & 130 & 300 & 375 & 410 \\
\hline
\end{tabular}

